\title{
Manoel Lopez Bichacho, a XVIth Century Leader of the Portuguese Nation in Antwerp and in Pesaro
}

Aron di Leone LEONI

\section{The expulsion of Portuguese Refugees from Antwerp} (JULY 1549) AND FROM FERRARA (SEPTEMBER 1549) ${ }^{1}$

On July 17th 1549, the Emperor Charles V expelled from Antwerp all the Portuguese who had arrived in that city during the previous seven years ${ }^{2}$. Most of these went in the direction of Ferrara where the Sephardic migration had been welcome for many years ${ }^{3}$. Some of the newcomers caught the plague during their journey across the Alps, in the Grisons. Fear of the Black Death became widespread in Ferrara and the frightened people asked Duke Ercole II to drive the newcomers away from the city. On September 14 th 1549 , a ducal

1 Abbreviations: AGR, Bxl (OFCB) = Archives Générales du Royaume, Bruxelles (Office Fiscal du Conseil de Brabant); AGR, Bxl (PEA) = AGR, Bxl (Papiers de l'Etat en Audience); ASAn = Archivio di Stato di Ancona; ASFe = Archivio di Stato di Ferrara; ASMo $(C D)=$ Archivio di Stato di Modena (Cancelleria Ducale); ASPs (ANA) = Archivio di Stato di Pesaro (Archivio Notarile Antico); JQR = Jewish Quarterly Review; REJ = Revue des Études Juives; $R M I=$ Rassegna Mensile di Israel.

${ }^{2}$ Cfr. P. GenarD, «Personen te Antwerpen in de XVIe eeuw voor het feit van religie gerechterlijk vervorlgt, lijst en ambtelijke bij-hoorige stukken», Antwerpsch Archievenblad 7 (undated, ca. 1870) pp. $377 \mathrm{ff}$.

${ }^{3}$ See A. di Leone LEONI, «La diplomazia estense e l'immigrazione dei cristiani nuovi a Ferrara al tempo di Ercole II", Nuova Rivista Storica 78 (1994) pp. 293-326: pp. 296-314. 
edict expelled all the Portuguese who had entered Ferrara during the previous four months ${ }^{4}$.

Samuel Usque described the wandering and the suffering of these unfortunate refugees ${ }^{5}$. According to the poet, Manoel Bichacho, a Portuguese living in Pesaro in the State of Urbino, persuaded Duke Guidobaldo II della Rovere to allow some of the refugees to settle in his countries ${ }^{6}$.

The same Samuel Usque moved to Pesaro in October 1549. He was not among the expelled but left Ferrara after a bitter quarrel with his employer, the powerful Brianda de Luna, widow of Diego Mendes?.

Until now the only information available on Emanuel Bichacho was the short reference made by Samuel Usque. Research carried in the Archives Générales du Royaume in Bruxelles and in the Archivio di Stato in Pesaro allowed me to identify him as the merchant Emanuel Lopez, one of the leaders of the Portuguese Nation in Antwerp and a member of the organisation who rescued hundreds of Marranos from the Iberian Peninsula.

2. The Escape of the Marranos from portugal to ANTWERP AND THENCE TO ITALY

In 1540, Charles $\mathrm{V}$ ordered an inquiry into the religious behaviour of the New Christians of Antwerp, whom he suspected of observing the Sabbath and «other strange Jewish ceremonies» ${ }^{8}$. The Emperor despatched to this city some of his

${ }^{4}$ ASMo (CD), Gridario, Registri di Grida Manoscritte, B.1b, Vol. 1534-1558. The document is published in extenso in A. di Leone LEONI, «La Nation Portughesa corteggiata, privilegiata, espulsa e riammessa a Ferrara (15381550 )", in press in the special number of the Rivista Italia dedicated to the Memory of Prof. Yosef Sermoneta.

${ }^{5}$ S. Usoue, Consolaçam as Tribulações de Israel Composto por Samuel Usque, Empresso en Ferrara en casa de Abraham aben Usque 5313 da criaçam, am d. 7 de setembro (Reimpr. Fundação Calouste Gulbenkian, Lisbon 1989) ff. 216r-217v: Dialogo Tercero, 36, Ytalia Año 5311.

${ }^{6}$ Usque Consolaçam f. $217 \mathrm{r}$.

${ }^{7}$ M. T. Guerrini, Samuel Usque e la Consolaçam as Tribulaçoens de Israel (unpublished master's degree: Ferrara University, 1997) p. 85.

8 P. GENARD, «Die nieuwe Christenen te Antwerpen in de XVIe eeuw», Antwerpsch Azchievenblad 3 (undated, ca. 1865) pp. 224-237; S. UlLMAN, Studien zur Geschichte der Juden in Belgien bis zum XVII Jahrhundert (Anvers 1909) p. 30; E. GINZBURGER, «Marie d'Hongrie, Charles V, les Veuves Mendes et les Néo-Chrétiens», REJ 89 (1930) pp. 179-192. 
top officers with the task of having three Portuguese merchants particularly suspected of heresy arrested 9 . However, the Burgomasters opposed this move and a long controversy arose between the city authorities and the Emperor's representatives ${ }^{10}$.

In december 1540 , many Portuguese refugees reached the port of Middleburg in Zeelande on board ships of the Royal Navy transporting crops of «Eastern Indian» spices from Lisbon towards the Flanders, whence the precious cargoes were sold and re-distributed to other European countries.

When it appeared that none of the passengers was provided with the royal licence necessary to leave Portugal ${ }^{11}$, Jerome Sandelin, the rentmeester ${ }^{12}$ of Bewesterschelt in Zeeland, ordered their arrest ${ }^{13}$. They were kept in jail for a few months. Juan Rebelo, the Portuguese Royal Feitor in Antwerp repeatedly interceded with Queen Mary of Hungary ${ }^{14}$ on behalf of his countrymen. In the end, all the prisoners but two were released upon payment of bail.

Two old men, Luis and Marco Fernandes, refused to profess belief in the divine nature of Christ and denied that he had

${ }^{9}$ AGR, Bxl (PEA), Reg. 128, ff. 283r-284v, Nov. 24th 1540: Queen Mary to Private Councillor Dr. Charles Boisot.

${ }^{10}$ AGR, Bxl (PEA), Reg. 73, ff. 111r-111v, Nov. 25th 1540: The Emperor to the Margraves, Burgomasters et Escoutètes [Dutch schouts 'local justice officers'] of Antwerp; AGR, Bxl (PEA), Reg. 1177/2, ff. 28r-29r, Feb. 21st 1541: the Magistrates of Antwerp send a Remonstrance à la Royne.

${ }_{11}$ The Alvará issued by King João III on July 18 th 1532 is published in extenso in the collection As Gavetas da Torre do Tombo (Lisbon 1960) Vol. I, Doc. 245 pp. 280-285. From witness depositions of different Captains of the Portuguese Royal Navy we learn that it was re-enacted in 1535 and again in 1538 and (ca.) 1541. AGR, Bxl (OFCB), B.1266: Jnformation commenchée ... le premier jour de juillet de l'an 1544, ff. $1 \mathrm{r}-40 \mathrm{v}$.

${ }_{12}$ Rentmeester (Dutch 'Fiscal receiver serving also as regional law-officer'); cfr. R. ANSWAARDEN, Les portugais devant le Grand Conseil des Pays-Bas (1460-1580), Glossaire, p. 349.

13 The list of the prisoners was published by GINZBURGER «Marie d'Hongrie» pp. 189-192. See Herman P. SAlOMON and A. di L. LEONI, «Mendes, Benveniste, de Luna, Micas, Nasci, The State of the Art (1532-1558)», JQR (1998) pp. 135-211: p. 145.

${ }_{14}$ Mary of Hapsburg, widow of King Louis of Bohemia and Hungary, governed the Low Countries on behalf of her brother Charles V. Cfr. E. de SEYND, Dictionnaire de l'Histoire du Belgique (Liege 1958) s.v. 
been crucified by the Jews. They were burnt at the stake at the beginning of 1541 by order of the queen-regent ${ }^{15}$.

In the meantime, other groups of Marranos succeeded in safely reaching the Flemish shores and continued their journey from Antwerp towards Ferrara. They started the «dificil caminho» ${ }^{16}$ along secondary roads to Cologne and from there they travelled on barges on the River Rhine to Basel or Constanz, and from there across the Alps by carriage continuing by boat along the rivers of Lombardy. Many of them were taken prisoners by a special police squad headed by Johannes Wuyustingh (alias João de la Foia) whom the Emperor had appointed commissioner «contra malos cristianos» ${ }^{17}$.

It was evident that most of these refugees were merely poor workmen who were not in a position to pay for their journey from Lisbon to Antwerp and thence to Ferrara. Fares had skyrocketed since 1539 when the Lisbon Inquisition had issued stern edicts against captains of ships who accepted to take New Christians on board. The Portuguese ports were strictly watched by the state policemen and by the Inquisition familiares ${ }^{18}$.

A commission of inquiry set up in Flanders came to the conclusion that there had to be some organisation which planned the escape of these poor refugees and paid their fares in the ships and for the rental of the carriages and the boats. It appeared that some Portuguese Merchants of Jewish origin in Lisbon and Antwerp had created a special fund to cover these enormous expenses. The Emperor Charles $\mathrm{V}$ and his sister Mary dedicated most of their energies to the purpose of discovering the trustees of these funds in the almost obsessive hope of laying their hands on them.

15 AGR, Bxl (PEA), Reg. 1504: undated [February 1541] list of prisoners: «Marco Fernandes passera le pas, Helena Mendis sa femme bannyie et ses biens confisqués, Katrina Alvares bannyie, Alvaro Gonsales absoluz, Martin Alphonso banny et ses biens confisqués ... Luys Fernandes passera le pas».

${ }^{16}$ I have borrowed this expression from USQUE Consolaçam f. 216r.

17 The letter of appointment was published in extenso by GENARD «Personen te Antwerpen» pp. 195-196. Cfr. SALOMON - LEONI «Mendes».

Is AGR, Bxl (PEA), Boîte 1177/2, f. 9v: Enquete faite a Middelburg le 17.2.1540 (= 1541, style de la Court). This collection of documents was drawn up partly in Flemish and partly in French. A full transcription will be published by H. P. SAlomon in Studia Rosenthaliana. 
For these reasons the interrogations of prisoners in Milan, Vigevano and Pavia was not aimed specifically towards the question of their religious behaviour. Johannes Wuyustingh, the Commissioner against the New Christians, was interested rather in discovering who had provided them with money for their journey in order to identify the administrators of the fabulous relief fund, the so called Caixeta das Elemosinas.

The prisoners were obviously not aware of Johannes Wuyustingh's complete lack of interest in the problems of their heresy. He was cruel, violent and pitiless ${ }^{19}$, continuously mistreating them and calling them despisingly Jewish dogs and renegades. They came from a country where this charge had already brought to the stake dozens of people and the prisoners believed that they were facing the same destiny. They were no heroes and when the commissioner promised to let them go free in exchange for detailed denunciation of the marranos of Antwerp, they gave in ${ }^{20}$.

In 1540 , various prisoners confessed under torture that they had received money from different merchants of Antwerp and denounced to this effect: Diogo Mendes Benvenisti, Gabriel de Nigro, Manuel Saran, Dominico Mendes, Lopes de Provincia and Manuel Lopes, whom they identified as the heads of the secret Rescue Commitee who had provided the Marranos with money "with the sole purpose of allowing them to reach the city of Salonica, in the parts of Turkey, in order to forswear the Christian faith» 21 .

According to these testimonies, Manuel Serrano and Emanuel Lopez were the ones who actually delivered the money to the refugees and provided them with carriages for the long journey ${ }^{22}$.

${ }^{19}$ Usque Consolaçam f. 209v, described Johão de la Foya (alias Wuyustingh) as «o mais cruel perseguidor que desque perdeo a casa teve Ysrael».

${ }^{20}$ They were in fact allowed to continue their journey towards Ferrara, after they signed (partly prefabricated) denounciations against the Marranos of Lisbon and Antwerp. The prisoners were deprived of all their goods, including clothes.

${ }^{21}$ See in Appendix, Docs. 1 and 2. I am deeply indebted to Prof. Herman P. Salomon of N. Y. S. University at Albany for calling these documents to my attention.

22 Witness deposition of prisoner Gaspar Lopes, the son of Baldassar de Castilia (Pavia, Dec. 24th 1540). This document was apparently used by Lucien WOLF, Essays in Jewish History (London 1934): «Jews in Tudor England», pp. 


\section{Emanuel Lopez in Antwerp}

Emanuel Lopez was already settled in Antwerp in 1535 and enjoyed a remarkable economic position: he hired the ship S. Maria da Consolacion and dispatched it to the Barbary Coast with a freight of fine clothes ${ }^{23}$.

He was included in an undated (ca. 1540) list of New Christians of Antwerp most of whom were considered rich merchants ${ }^{24}$.

Other information on Emanuel is provided by the testimonies of prisoners jailed in Lombardy in 1540 , who described him as a succesful merchant of approximately 35 years of age. Some of these refugees had met with him before leaving Antwerp and had received, together with material help, moral support and the last instructions for the journey.

Emanuel had a brother called Antonio Fernando of approximately 25 years of age, a merchant of woollen clothes in Antwerp 25. Another brother called Odoardo Lopes lived in Ancona in 1539 where he entrusted Emanuel with the charge of collecting from Odoardo Pinto a credit of 22 golden ducats ${ }^{26}$.

The protagonist of our essay is not to be confused with the other Emanuel Lopes who arrived in Zeeland in 1544, was

80-81. This author was mainly interested in finding the names of the Marranos living in London in 1540, and he did publish (loc. cit.) a list of them.

23 J. A. Goris, Étude sur les colonies marchandes méridionales: Portugaises, Espagnoles, Italiennes à Anvers, de 1488 à 1567 (Louvain 1925): «Tables des navires affretés en 1535», pp. 162-163.

24 «Todos estos son xpianos nuevos, de nacion portugueses, habitan Anveres, son mercantes los mas, y muchos dellos muy ricos" (AGR, Bxl [PEA], Boîte 1504: loose sheet originally undated). The document bears the posthumous note «1540/1541» but in my opinion the list was drawn up at the beginning of 1540 , as it includes some people who later left the city.

25 «Antonium Fernandum fratrem Emmanuelis Lopes in Anversia, mercatorem pannorum lane, annorum 25 vel circa». Witness deposition of prisoner Gaspar Lopes (Pavia, Dec. 24th 1540). Emanuel's brother is not to be confused with the almost homonimous Antonio Fernandez who was also a leader of the Portuguese Nation of Antwerp, and a member of the famous Pepper-Pool together with Diogo Mendes. He was the victim of a long trial on charges of «monopolist practices» and Jewish heresy. Cfr. ANSWAARDEN Les portugais pp. 259-278. On Fernandez' role in the negotiations with Girolamo Maretta, Duke Ercole's envoy to Antwerp in 1538-1539 see LEONI «La diplomazia estense»pp. 304,306

${ }_{26}$ ASAn, Notary Antonio Pavesi, Vol. 957, ff. 120r-v. See also, ASAn, Notary G. B. Agli, Vol. 489, Jan. 7th 1539. 
immediately arrested, kept prisoner for a few months and eventually released after payment of bail. This other Emanuel was apparently the nephew of Fernando Alvares. Towards 1550 , he was the protagonist of a prolonged process with which we will not deal at this point.

\section{The first Sephardi Merchants in Pesaro}

We do not know when Emanuel Lopez left Flanders, nor do we know where he first settled in Italy. He probably lived for a while in Venice and later in Ancona whence he moved to Pesaro, a harbour-townlet in the States of the Duke of Urbino with an ancient and small Jewish Community ${ }^{27}$.

In 1548 , there was not a Sephardic Settlement in Pesaro even though the town was regularly frequented by Spanish and Portuguese merchants from Ferrara and Ancona, some of whom stayed in for varying lengths of time.

In 1535, Masio (Meir), the son of the Ashkenazi merchant Ysac de Nocte from Ferrara, was operating a commercial company together with the banker Lustro di Simuel Teutonico da Pesaro. They later extended their activities to Ancona. Specially noteworthy among their customers is the Sephardi Ysac Bondi ${ }^{28}$. They traded fine clothes from Flanders against Balcanic leather and skins and engaged also in the commerce of locally manufactured products ${ }^{29}$.

In 1541, after the expulsion of the Jews from Naples, a part of the family Zarfatti settled in Pesaro and engaged in financial and commercial activities. They did not stress their Sephardic origins but simply presented themselves as Neapolitan Jews ${ }^{30}$.

27 See G. BerRetTA, «La presenza ebraica nelle carte dei secoli XV-XVII dell'Archivio dei Stato di Pesaro», to be printed in Italia Judaica: Vol VII, Atti del Convegno Internazionale di Studi su Storia e Cultura degli Ebrei a Roma e nello Stato Pontificio (Reggio Emilia 15-19 giugno 1998).

28 Wide information on Ysac Bondi is provided in LEONI «La Nation Portughesa».

29 ASAn, Notary A. Pavesi, Vol. 958, 4 and 18 Jan. 1535; ASPs (ANA), Notary G. A. Garattoni, Vol. 1544-1545, ff. 425r-427v, 7 Aug. 1545.

${ }^{30}$ See, for instance, ASPs (ANA), Notary G. Antonio Garattoni, Reg. 15461549 , f. 11: on july 21st 1546 the lawyer Jacob Giagnolo acknowledged that he owed "Abraam Zerfhati hebrei neapolitanj habitatoris Pisauri" 345 scudi. For 
The first Levantine merchant to take up residence in the Adriatic town was probably a certain Abraam Lubello, a leather merchant ${ }^{31}$. Starting from 1547, we find occasional mention of the Portuguese Moshe Cassam, who was engaged both in local trade and in financial operations ${ }^{32}$.

In 1550, after a bitter quarrel with his mother Benvenida, Yehuda (son of Don Samuel) Abravanel moved to Pesaro where he reached his lover Luna, a Portuguese girl of easy virtue ${ }^{33}$. Yehuda was apparently in Pesaro in 1558, when the banker Ysac da Fano of Ferrara charged him with the task of collecting from Ysac Trabot, a former banker in Ancona now living in Pesaro, the amount of 550 golden scudi ${ }^{34}$.

\section{EMANUel Lopez Bichacho In Pesaro (1547-1558)}

In the beginning of 1547, Emanuel Lopes Yspano de Portugalia ${ }^{35}$ was degens (a temporary resident) in Ancona: on February 7 th of that year he supplied 10 pieces of finest English cloth to a merchant of Falconara for the amount of 100 scudi to be paid within 12 months ${ }^{36}$.

In 1548, Emanuel Bichacho obtained from Duke Guidobaldo della Rovere the condotta ('licence') of a pawnbroking bank in Pesaro for a period of three years and undertook to pay the amount of 3.000 golden ducats, corresponding to an annual fee

the analogous behaviour of their relatives Abravanel in Ferrara see A. di Leone LEONI, «Nuove Notizie sulla Famiglia Abravanel», Zakhor 1 (1997) pp. 153-206: pp. 155-159.

31 ASPs (ANA), Notary A. Allegrucci, July 27th 1548.

32 ASPs (ANA), Notary A. Allegrucci, Oct. 24th 1548; ASPs (ANA), Notary G. A. Garattoni, Vol. 1550-1553: May 13th 1549 and March 18th, 1550; Notary Alessandro Allegruci, Reg. 1547-1554, Oct. 29th 1550.

33 For the whole history see LEONI «Nuove notizie» pp. 165-166.

34 ASFe, Notary A. Coccapani, Pacco 9, 24th Nov. 1558.

35 The term Yspano de Portugalia, generally accompanied by the specification Hebreo (which did not occur in the present case), was frequently used for the Portugueses of Ancona during the forties of the xvith century.

36 ASAn, Notary G. B. Agli, Reg. 222, f. 14, Febr. 7th 1547. Emanuel Lopes de Portugalia is mentioned in still another deed drawn up in Ancona on Dec. 20th 1548. At that time he had already moved to Pesaro and was represented by Joseph Ruben who tried to collect from a certain Antonio Petro Bassi the amount of 115 golden scudi, together with interest for delayed payment (ASAn, Notary G. B. Agli, Reg. 223, f. 336v). 
of 1.000 ducats. The first instalment was paid in Venice into the hands of the ambassador of Urbino in that city ${ }^{37}$.

During the first months of his stay in Pesaro, Emanuel used his Portuguese baptismal surname together with his Jewish one, and he signed himself «Emanuel Lopez Bichacho, Portuguese Jew and banker in Pesaro». It is precisely thanks to some 1548 deeds that we can identify the banker Bichacho with Emanuel Lopez, the former merchant of Antwerp ${ }^{38}$.

The bank managed by Emanuel had belonged to the late Zaccaria da Volterra and to his son Angelo for many years. Bichacho entered in some form of financial partnership -or familiar relationship- with him, and in 1551 he lived in the "house of Angelo" in a building close to the Italian synagogue ${ }^{39}$. Whatever the character of their relationship, Emanuel did not join the local Jewish Community but made a point of calling himself a Portuguese Jew and described the other few Portuguese merchants living or trading in his town as members of his same Nation.

Many documents provide evidence on Emanuel's wide financial and commercial activities. Far from limiting his work to pawnbroking inside the walls of his bank ${ }^{40}$, he lent medium and large sums to artisans, farmers, merchants, businessmen and even municipalities, in Pesaro and in the surrounding regions, generally under the form of chirographic deposits ${ }^{41}$.

Sometimes, Emanuel accepted payment in the form of goods (especially leather) or agricultural products such as grain and oil. On September 22nd 1553, Colonel Antenore Leonardi acknowledged that he owed Emanuel Biciaccio and «his associate» Angelo da Volterra the amount of 190 scudi for which he had already provided appropriate securities. He asked for and obtained them back and undertook to supply the equival-

\footnotetext{
37 ASPs (ANA), Notary Francesco Brettarini, Reg. 1544-1549, ff. 217r-222v.

38 ASPs (ANA), Notary F. Brettarini, Box 1544-1548, Nov. 8th 1548 and passim; ASPs (ANA), Notary F. Brettarini, Pacco 1545-1552, April 7th 1551.

${ }^{39}$ ASPs (ANA), Notary Almerico Emilioni, Reg. 1536-1557, ff. 450r-452r.

${ }^{40}$ This activity consisted in lending generally limited amounts of money for a short term period with a guaranty.

${ }^{41}$ In this case the only guaranty was provided by the undertaking, signed by the depositary in front of the notary, to pay the money back.
} 
ent amount of money in pure, good natural «yellow» olive oil at the market-price ${ }^{42}$.

Other transactions were a little bit more complex. On February the 23rd 1552, Emanuel Bichacho happened to have a credit with the merchant Hieronimo Pervino «for a large amount of good money». At the same time, Emanuel owed the Portuguese Jew Samuel Benmaior 225 ducats. Bichacho asked his debtor to supply Samuel with the equivalent value in woollen clothes ${ }^{43}$.

In Pesaro, Bichacho did not engage principally in his former specialty, the trade of Flemish clothes. He however dealt occasionally with these products. On May 28th 1555, the Levantine merchant Abraam Menda living in Ferrara entrusted Ysac, the son of don Samuel Abravanel, with the charge of collecting from Emanuel Bichacho and his associates Abraam and Samuel Catalano 1.150 golden scudi, relating to a supply of woollen clothes ${ }^{44}$. Abraam Catalano with his brother Samuel ${ }^{45}$ settled in Pesaro towards 1548, apparently after a stay in Ancona where Abraam had wide interests ${ }^{46}$.

Abraam acted frequently as representative and feitor of Emanuel Bichacho and later was somehow associated with his business enterprise ${ }^{47}$. This also became a family relationship

${ }^{42}$ ASPs (ANA), Notary Francesco Fattori, Reg. 1542-1553, ff. 205r-205v.

${ }^{43}$ ASPs (ANA), Notary F. Brettarini, Reg. 1545-1552, sub data. Samuel Benmaior received only 84 scudi worth of clothes. For the remaining amount a delayed payment was agreed.

${ }_{44}$ ASFe, Notary Andrea Coccapani, Pacco 9, Mandatum D.ni Abraam Menda in M.cum D.num Jsaach Abravanelli, May 28th 1555. The indication of 1.150 golden scudi was cancelled from the deed. Samuel Catalano is described as Abraam's brother.

${ }^{45}$ ASPs (ANA), Notary Francesco Brettarini, B. 1544-1549, Nov. 12th and 23rd 1548.

${ }^{46}$ On Dec. 12th 1552, Abraam entrusted Davit Cassam and his brother Jacob, living in Ancona, with power of attorney enabling them to deal with his business and to collect all of his credits (ASAn, Notary G. B. Agli, Reg. 221, ff. $451 \mathrm{r}-451 \mathrm{v})$.

${ }^{47}$ On Nov. 12th 1548, two representatives of the Municipality of Monte Bovagino borrowed 45 golden scudi from the banker «Emanuele Lopez Bizaccio», represented by Abram Catalano (ASPs [ANA], Notary Francesco Brettarini, Reg. 1544-1549, ff. 220r-220v). 
when Samuel, Abraham's brother, married Ora, Emanuel's daughter ${ }^{48}$.

\section{The Portuguese Merchants invited to Pesaro (1551- 1552)}

I did not succeed in finding any evidence of an official invitation or of a safe-conduct, supposedly extended by the Duke of Urbino to some of the Portuguese expelled from $\mathrm{Fe}$ rrara in 1549, as suggested by Samuel Usque. The notarial deeds relating to 1550 and 1551 do not supply information on Portuguese people recently settled in Pesaro, the only remarkable exception being perhaps provided by branchs of the Namias ${ }^{49}$ and Roves ${ }^{50}$ families.

At this point we have to take into account the problem posed by the wrong dating of the «desterro de Ferrara» ${ }^{51}$ by Samuel Usque. In effect, while all the documentary sources are dated between September and October 1549, Usque entitled the chapter 36 of his Third Dialogue: "Ytalia Año 5311 [= 15501551]» 52. Scholars have pointed out that Usque addressed himself to readers who were well aware of the recent events: he did not therefore take too much care in calculating the dates according to the Jewish Calendar ${ }^{53}$.

48 ASFe, Notary Andrea Coccapani, Pacco 9, May 28th 1555; ASPs (ANA), Notary Francesco Fattori, Reg. 1554-1558, Dec. 7 th 1558. See Doc. 4 in Appendix.

${ }_{49}$ On Oct. 21st 1550, Josef and Ezdra (sic), the sons of Moises Namias, living in Pesaro, agreed that Ezra was to manage the family enterprise. The later declared to be holding 1.376 scudi belonging to their father (ASPs [ANA], Notary Almerico Emilioni, Vol. 1547-1554, ff. 461r-462v).

so In several deeds drawn up in Ancona in 1550, «Isac Zaccaria Roves hebreus Portughensis pisauriensis» is mentioned. ASAn, Notary G. B. Agli, vol. 205 f. $173 \mathrm{v}$ and passim. Cfr. V. BONAZzOLI, «Ebrei italiani, portoghesi, levantini ad Ancona», in G. CozZI (ed.), Gli Ebrei e Venezia, Secoli XIV-XVIII (Milano 1987) pp. 727-770: p. 757, note 66.

51 In USQUE's Consolaçam the expression desterro is found only in the Index, p. 216.

${ }^{52}$ See the remarks by Y. H. Yerushalmi, «A Jewish Classic in the Portuguese Language, Estudo introdutorio" (to the Reimpr. of the USQUE Consolaçam [Lisbon 1989]) pp. 1-123: pp. 79-80.

53 See M. A. COHEN, Foreword and Appendixes to the English Translation of Samuel Usque's Consolation for the Tribulations of Israel (Philadelphia 1977) p. 316 , note 15 , and p. 281 . According to this author, other errors were probably due to simple printing mistakes, such as the substitution of a digit with another in the press. 
In the light of new documentary evidence, we may wonder if the term Ytalia was used by Samuel Usque in order to include the episode of Pesaro among the major historic events of this period and to connect more importance to the role of Emanuel Bichacho. It is therefore possible that Usque used the date 5311 only loosely in connection to the expulsion from Ferrara in order to make it coincide with the moment of the actual arrival of a group of Portuguese merchants in Pesaro towards the end of 1551 or at the beginning of 1552 .

The banking licence granted to Emanuel Bichacho in 1548 expired in 1551. It was renegotiated and reconfirmed in the spring of this year. The long and detailed specifications were registered in a legal contract comprising a new and quite unusual clause. By a stroke of good luck we found it transcribed and inserted in yet another deed. In April 1552, in the Ducal Chancellery of Pesaro, Emanuel Bichacho undertook to pay the Ducal treasurer an additional amount of 1.050 ducats, according to detailed terms. In exchange, Emanuel was granted the right of keeping his residence in the city of Pesaro during the term of the banking licence, to live in this city safe, sure and undisturbed together with his family, heirs, grandchildren (or nephews) ${ }^{54}$ and together with the members of (up to) 35 other families belonging to the Portuguese Nation, who were also allowed to settle and live within Pesaro ${ }^{55}$.

On August 10th 1552, Emanuel Bichacho provided a list of 10 householders belonging to the Portuguese Nation ${ }^{56}$ and stated that, availing himself of a specific Ducal permission, he allowed them to operate under his licence. Their financial dealings were however to be limited to money-lending in the form of chirographic deposits with the exclusion of any loan secured by guaranty. No limit was set to their commercial activities. In exchange, the newcomers were requested to con-

54 The latin word nepotibus has the double meaning of 'grandchildren' and 'nephews'.

55 ASPs (ANA), Notary Almerico Emilioni, Reg. 1536-1557, ff. 387r-388v, April 20th 1552.

56 They were: Joseph Tobi, Samuel Binmaiori, Joseph Cavalieri and his brother Mordechai, the brothers Ioseph and Esdra Namias, Moise Avensechem and his father in law, Salomon Atias, Samuel Rubra, Madama Rachela Abiacari and her sons, Abram Iglioni with all their families. 
tribute to the payment of the (additional) taxation due to the Duke ${ }^{57}$.

This understanding was subsequentely broken as some of the would-be partners judged the share they were expected to pay to be excessive ${ }^{58}$. Nevertheless, a new form of agreement was subsequently reached as most of these people remained in Pesaro.

So, in a quiet and almost unofficial way, by means of a short clause inserted in a banking licence, Duke Guidobaldo della Rovere granted right of residence to a group of Portuguese people and recognized them as members of a Jewish Nation separate and distinct from the local Jews. As we have already seen, there were other Portuguese who lived and performed their economic activities in the town but this was surely the first time that the term "Portuguese Nation» was officially adopted in the Dukedom of Urbino.

However, their arrival in Pesaro does not seem related to the events occured in Ferrara in the autumn 1549. The Portuguese had been readmitted to that city in February 1550 and the terror of the plague had been completely forgotten.

\section{The Marranos of AnCona admitted to Pesaro and SUBSEQUENTLY EXPELLED (1556-1558)}

In 1555, Pope Paul IV withdraw the privileges granted to the Portuguese living in Ancona and started a violent persecution against them. Twenty five ex-marranos resisted steadfastly under torture, refused to be reconciled to the Church, and were burnt at the stake. In 1556, some Portuguese who had been arrested in Ancona succeeded in escaping and reaching Pesaro, where they found shelter. The warm welcome granted by the Duke of Urbino to these refugees did not fall within the economic projects, which were planned only later.

From the correspondence between Guidobaldo della Rovere and Ercole II of Ferrara, we learn that there was a certain degree of collaboration and complicity between the two Italian princes, both of whom were shocked and horrified by the persecutions carried out by Pope Paul IV in Ancona.

57 ASPs (ANA), Notary Almerico Emilioni, Reg. 1536-1557, ff. 450r-452r. The document is published in Appendix, Doc. 3.

58 ASPs (ANA), Notary A. Emilioni, Reg. 1536-1557, ff. 456r-456v. 
Between March and April 1556, Guidobaldo sent to Ercole II different letters which seem to be code messages: the «Portuguese captain» Pinhero had been involved in a «duel» and requested a written opinion from the Prince of Ferrara. Other messages mention a "captain Francesco Pigneiro» ${ }^{59}$. Actually, Petro Pinhero (alias Yoseph Navarro) had been one of the first leaders of the Portuguese Nation of Ferrara. He had established wide commercial relations in Ancona and was among the Portuguese arrested in that city. «Francesco» was perhaps a codereference for Abram Namias, called Francese, a leader of the Portuguese Nation of Ancona and the commercial representative of Ysac (the son of Samuel) Abravanel in that city. Both of them were promptly admitted to Ferrara and were granted a generous safe-conduct ${ }^{60}$.

It was only later, in July 1556, that Gracia Naci conceived her famous and unlucky plan to engage in an open commercial war against the Church, boycott the Ancona entrepot , and develop the rival port of Pesaro as a new centre for maritime trade between Italy and the Levant ${ }^{61}$.

Scholars have assumed that the number of the Portuguese who settled in Pesaro in 1556 was significant. However strange it may appear, we do not know how many people were in this group, nor do we know about their commercial activities or about the financial means available to them after the confiscation and pillage performed by the papal police in Ancona.

The case does not fall within the scope of the present research, aimed at the Bichacho family. We cannot however refrain from

\footnotetext{
59 ASMo, Cancelleria Estero, Carteggio Principi Esteri, B. 1462.

${ }^{60}$ Cfr. LEONI «La diplomazia estense» pp. 317-318.

${ }^{61}$ Wide information on the whole history and a detailed account of many of the Responsa of contemporary Rabbis are provided by C. ROTH in The House of Nasi: Doña Gracia (Philadelphia 1948; reprint 1977) pp. 134-175, and by I. SONNE, Mi-Paulus ha-rebi $i$ ad Pius ha-hamiši (Jerusalem 1964) pp. 149-157 with the full edition of Benjamin Nehemiah ben Elnatan's chronicle Dibré hayamim (Appendix, pp. $79 \mathrm{ff}$.); cfr. S. W. BARON, A Social and Religious History of the Jews (2nd ed.: Philadelphia 5730 [=1970-1971]) Vol. XIV pp. 35-43 and 320 , note 39, where a list of the main Rabbinical responsa is provided; and $\mathrm{H}$. H. Ben SASSON, A History of the Jewish People (Cambridge, Mass., 1976) pp. 667-669. See the discussion and literature quoted in A. di L. LEONI, «Per una Storia della Nazione Portoghese ad Ancona», in P. C. IOLY ZoraTTinI (Ed.), Miscellanea di Studi sul Marranesimo (Florence, in press).
} 
noting how the large amount of documents examined in Pesaro has not produced, so far, much information on the members of the Portuguese settlements between 1556 and 1558 .

However, I could find a 1556 notarial deed relating to trade between the Levant and Pesaro which is perhaps of revealing importance. It is the matter of the transcription of a deed, drawn up in Alessandria, whence three Levantine merchants ${ }^{62}$ entrusted the Portuguese Ysac de Stella, Abraam and Yacob Alalvo and Abram Guat, living in Pesaro, with the task of recovering in the island of Candia the goods dispatched in a lost Turkish ship (seized by Venitian or Maltese pirates) ${ }^{63}$. From other sources we know that in this period Christian corsairs frequently attacked Ottoman ships directed to Pesaro ${ }^{64}$.

Most of the other documents so far available are related to local traffic and not to international trade. I feel it is my duty to provide some concise information.

1) On August 10th 1557, a certain Thomas Marroli de Monticulo bought from the Levantine merchant Abraam Molcho 4 salmas of grain and engaged to pay the amount of 43 golden fiorini ${ }^{65}$.

2) In 1557, the Portuguese Jew Emanuel Endrighes (alias Davit Cohem) entrusted a Florentine merchant with the charge of claiming his credits in Ancona ${ }^{66}$.

3) Yomtob Athias and Samuel Benmmaior acknowledged to owe Samuel Albacar 166 scudi for a supply of finest London clothes and undertook to settle their debt within a year ${ }^{67}$.

4) We could not find any information on the activities of Jeronimo Vargas, who in 1557 lived in Pesaro ${ }^{68}$, nor we know

\footnotetext{
${ }^{62}$ They were: Abraam Namias levantinus, Sallamon Cazzam levantinus, David Guaschon levantinus.

${ }^{63}$ ASPs (ANA), Notary Alessandro Allegrucci, Reg. 1547-1554, Jan. 5th 1556.

${ }^{64}$ D. Kaufman, «A letter from the Community of Pesaro to Don Joseph Nassi», JQR 4 (1891-1892) pp. 509-512.

${ }_{65}$ ASPs (ANA), Notary Francesco Fattori, Jan. 5th 1557.

${ }^{66}$ ASPs (ANA), Notary Alessandro Allegrucci, Reg. 1547-1554, ff. 399r-400r.

67 ASPs (ANA), Notary Francesco Fattori, Sept. 22th 1557.

${ }^{68} \mathrm{Cfr}$. A. di Leone LeONI, «New Information on Yom Tob Atias (alias Alvaro Vargas) co-publisher of the Ferrara Bible», Sefarad 57 (1997) pp. 271276: p. 275.
} 
about his (probable) kinship with Salomon Atias who, as we have seen, had settled in this town since 1551 .

Research in the wide and rich Notarial Archives of Ferrara have not provided, until now, any evidence of links between the important Portuguese Nation of this city with the not too distant settlement in Pesaro.

Most of the available information on the ill-conceived and ill-planned boycott of Ancona derive from Rabbinical literature. In effec, the attempt was opposed by important Rabbis in the Levant. Even some Communities of the Sephardic Diaspora did not adhere to it. In my opinion these were not however the main reasons for the failure. The port of Pesaro was too small and badly equipped and -what is perhaps still more important- it was not frequented by the Levantine merchants who should have been the natural partners of the ex-marranos as they were the very ones who had adequated channels to convey the ponentine manufactured goods towards the oriental markets ${ }^{69}$.

Some authors have stressed that the Italian Jews continued to dwell in Ancona but these were not the only nor the most important professing Jews who stayed in the Papal city. They were powerless and had never played a relevant role in international commerce. The Levantine merchants remained in Ancona as well, thereby depriving the Portuguese of Pesaro of their invaluable collaboration ${ }^{70}$.

The Duke of Urbino was embittered and disappointed by the failed boycott and by the unfulfilled attempts to develop the port of his city. Overwhelmed by diplomatic pressure from the Church, in March 1558, he yielded to the wishes of the Pope and

${ }^{69}$ On the commercial links between Portuguese and Levantine merchants in Ancona before 1555 see BONAZZOLI «Ebrei italiani» pp. 727-770.

70 Strangely enough some historians dealt widely with the supposedly contrasting interests of Italian and Portuguese Jews but they did not pay attention to the passive role played by the Levantine Community of Ancona which accepted confinement into the Ghetto and (temporary) deprivation of its commercial rights. On the (supposed) rivalry between Italian and Portuguese Jews in Ancona see A. TOAFF, «L'Universitas Hebraeorum Portugalensium nel Cinquecento, interesssi economici ed ambiguità religiosa», in Mercati, mercanti, denaro nelle Marche (secoli $X I V-X I X$ ), published by the Deputazione di Storia Patria per le Marche (1982) pp. 115-145: pp. 125-126, 131. Cfr. the different conclusions of BONAZZOLI «Ebrei italiani» pp. 727-732. 
decreed the expulsion of all the Marranos, including those who had already been living there before the Ancona affair ${ }^{71}$.

Historians have stated that Guidobaldo granted those expelled with the necessary time to settle their business, but it was not so. At least in the case of Emanuel Bichacho, the departure from Pesaro was not painless. From a couple of 1558 notarial deeds, we learn that the Duke ordered the confiscation of all the properties and goods belonging to Emanuel and to his son in law Samuel Catalano. This angry provision was carefully enforced. Furthermore, all the debtors of the two Portuguese bankers were exempted from paying back whatever amount of money they had received.

The two bankers succeeded in escaping from Pesaro. Ora Bichacho, the wife of Samuel, was kept prisoner for a long time and moved from place to place. On December 17 th 1558 , Guidobaldo ordered that she should be free.

\section{EPILOGUE}

We do not know what happened to Emanuel Bichacho and to his family afterwards. Apparently, they did not settle in Ferrara, the only Italian city where the ex-marranos were accepted. We must perhaps assume, par exclusion, that they reached the Levant.

Angelo di Zaccaria da Volterra obtained the licence of the bank which had formerly belonged to his father and later to Emanuel. He also got the job of Ducal cashier. Guidobaldo della Rovere was so pleased with his performance that he praised him publicly and granted him the perpetual exemption from dazi e gabelle (state and city import and export-duties) ${ }^{72}$.

Abram Catalano moved to Ferrara before the Ancona affair. He married Stella Barocas, the daughter of the late Yosef 73 and the niece of Chyia (Vita) Barocas, one of the outstanding

${ }^{71}$ Cfr. A. Milano, Storia degli Ebrei in Italia (Torino 1963) pp. 251-252.

72 ASPs, Archivio Ducale, Vol. N. 3, Concessiones, exemptiones ac privilegia 1428-1597, ff. 88v-89r, Oct. 7th 1560 .

${ }^{73}$ Yosef Barocas had died in Ancona before 1548, when the rest of the family moved to Ferrara. In 1568, Stella and Abram were still living in via Gattamarcia, close to the Portuguese Synagogue (ASFe, Notary Giacomo Conti, Pacco 12 S, July 18 1568). 
personalities of Ferrara who served as Parnas (member of the Board of Directors) of the Portuguese Nation for many terms.

Abram Catalano performed wide commercial activities together with his uncle in law ${ }^{74}$ : he was later associated with a company whose partners were Agostino Anriques (also on behalf of Doña Gracia Naci), Henrique Nunes junior (on behalf of his family) and Chyia Baroquas.

Between 1561 and 1565, Abram Catalano lived in the ghetto of Venice, after which he returned to Ferrara. When the company with the Anriques was dissolved, the accounts between the partners were settled by means of arbitration ${ }^{75}$.

Some of the Portuguese merchants who had settled in Pesaro moved to Ferrara. This was the case of Yoseph and Ezra Namias ${ }^{76}$, Yacob Allalvo and his brother in law Moise Avensechem ${ }^{77}$.

\footnotetext{
${ }^{74}$ Chyia was the feitor of Violante Anriques (alias Vellida Benvenisti), the widow of Nuno Anriques and the mother of Marquesa (alias Reina Benvenisti) and of the famous adventurer Henrique Nunes junior.

75 ASFe, Notary Giacomo Conti, Pacco 9, July 20th 1561: Approbatio et ratificatio Magnificorum D.ni Augustini Anriques, et D.ni Chia Barrochas de dichiaratione facta per D.num Abraam Catalanum ... in civitate Venetiarum in lingua lusitana; ASFe, Notary G. B. Monti, Reg. 8252, Oct. 1st 1565: Enrico Nunes (junior), hebreus, entrusts David Cajati with the task of collecting from Abraham Catalano all his credits, consisting in bonds issued by the King of France and deposited in different trading banks; ASFe, Notary Giacomo Conti, Pacco 13-S, March 27 1572: Mandatum heredum Henrici Nunez. The arbiters imposed on Abram to pay 1.000 scudi to the heirs of Nuno Anriques.

${ }_{76}$ ASFe, Notary Andrea Coccapani, Pacco 9, March 3rd 1559: Absolutio Mag.ci D.ni Joseph [quondam] Abraam Namyas a mag.ca D.na Hester Namyas eius sorore. Seven years before in Pesaro, on Oct. 21st 1552, Joseph Namias acknowledged to hold in a trading bank of Lyon 1.000 scudi in bonds issued by the King of France. Joseph undertook to pay this sum to his sister Hester, living in Ferrara, on her marriage (ASPs [ANA], Notary A. Emilioni, Reg. 1536-1557, ff. 461r-462r).

77 ASFe, Notary Andrea Coccapani, Pacco 9, Feb. 2nd 1559: Absolutio D.ni Moysis Abensusem hebreij portughensis a D.no Jacob Acchar Hebreo Lusitano. See also A. di Leone LEONI, "I marrani di Coimbra denunciati al Papa dall" Inquisizione Portoghese nel 1578: Il loro status giuridico in diversi Stati italiani», Zakhor 2 (1998) pp. 73-109: p. 95.
} 


\section{APPENDIX}

Doc. 1 (Dec. 20th 1540): The Portuguese Michael Nones imprisoned in Pavia's jails discloses under torture the names of the members of the Rescue Committee.

Constitutus Michael Nones filius quondam Joannis de civitate Lisbone ... Domini jusserunt eum ligari et altiarj per brachia tria vel circa, qui altiatus, ... jnterrogatus ut nominet eos socios qui sunt detentj et ad quem finem jbant jn dictis partibus Turchie et si dictj eius socij sunt hebreij secrette, licet extrinsece nominarj se faciant pro bonis xpianis, et an vivant more hebraico et si jntendebant jre ad locum Salonichij ad negandum fidem $\mathrm{Xpi}$, respondit quod eius socij detentj sunt jnfrascripti videlicet: Giam Lopes, Doardus Rodricus, Marcus Badiglia, Manuel Fariera, Andreas Lopes, Biento Dies, Gabriel, Gaspar Lopes, Rodricus Antones, et quod ipse constitutus, Gioannes Lopes et Doardus Rodricus ex civitate Lisbone discesserunt et venerunt ad civitatem Anversie in Flandria pro eundo postea ad Salonichum pro se faciendis hebreis prout dixit et postea die vigesima seconda junij, si bene recordatur, jpse constitutus, Marcus Badiglia, Gioannes Lopes, Doardus Rodricus una cum uxoribus suis et filijs discesserunt ex civitate Anversie veniendo versus Jtaliam pro eundo ad Salonicum ad renegandam fidem Xpi prout super dixit et jnterrogatus respondit quod jpse constitutus et alij eius socij supra nominatj et detentj cum eo licet extrinsece appareant xpiani, tamen secrete sunt hebreij et vivunt secundum legem hebraicam.

Jnterrogatus an jpse constitutus vel eius uxor vel Gabriel eius cognatus habuerint aliquas peccunias ab aliquo pro eundo ad dictum locum Salonichij pro se faciendis hebreis respondit quod jpsi non habuerunt aliquid sed Doardus Rodricus et eius socjus jn Anversia habuerunt a Lope de Provenza scutos decem et octo pro eundo ad Salonichum ad effectum supradictum, que pecunie erant ex bursa caritatis

Jnterrogatus qui sunt jlli qui teneant bursam caritatis in Anversia, respondit quod jnfrascripti sunt jlli qui tenent bursam caritatis, videlicet: Dieghus Mendes, Manuel Sarran, Dominicus Mendes, Manuel Lopes et Lopes de Provenza et quod etiam in civitate Lisbone adest Andricus Nones et Nones Andricus fratres qui similiter tenent aliam bursam caritatis, qui dant peccuniam pro eundo usque ad Anversiam jllis qui volunt petere Salonichum pro se faciendo hebreos ut supra dixit, et postea jlli quos supra nominavit tenent bursam caritatis novorum xpianorum in Anversia, dant similiter peccunias jllis 
petentibus jre ad Salonicum ad effectum supradictum, et quod jpse constitutus nihil petijt ${ }^{78}$.

Doc. 2 (Dec. 24th 1540): The Portuguese Gaspar Lopes, prisoner in the jails of Pavia, reveals under torture that Emanuel Lopes is the holder and the manager of the Rescue Fund.

... Jtem cognovit et cognoscit Manuellem Lopem in Anversia, negociorum gestorem burse falsorum xpianorum, annorum 30 vel circa a quo jpse constitutus cum eius familia habuit scutos 46 pro eundo ad Salonichum ad renegandam fidem Xpi. Et insuper dictus Manuel dedit de bursa dicte caritatis scutos decem pro quolibet 25 alijs personis jnter masculos et feminas qui similiter jbant ad Salonicum ad effectum ut supra, pueris autem dedit et dabat scuta quinque auri pro eodem effectu et

Jnterrogatus ut exprimat nomina et cognomina eorum qui habuerunt supradictas peccunias a suprascripto Manuelle, respondit quod Odoardus Fernandus et eius uxor cum tribus filijs, Simon Fernandus et eius uxor cum tribus filijs, Manuel Rodricus, Franciscus de Valle Dolvia. De alijs non recordatur.

Et quod Manuel Lopes providit jpsi constituto et socijs plaustrum pro conducendo eos et dedit jteneralium jn scriptis ad Salonicum ${ }^{79}$.

Doc. 3 (Aug. 10th 1552): Notary Almerigo Emilioni confirms and states that Emanuel Bichacho was granted a new banking licence. According to it, some families of the Portuguese Nation are equally allowed to settle within Pesaro and enjoy Emanuel's privileges. Manuel states the names of ten Portuguese householders.

Jn Christi nomine amen. Anno ab eiusdem Domini circumcisione millesimo quingentesimo quinquagesimo secundo ... die decima mensis augusti.

Omnibus hoc praesens instrumentum inspecturis sit notum:

che essendo nella capitolazione ultimamente fatta fra l'Jll. ${ }^{\text {mo }}$ et Ecc. ${ }^{\text {mo }}$ S.r Duca d'Urbino et noj Emanuele Bicciaccio portughese hebreo banchiero in Pesaro, fra l'altre cose si contenghi che nessuno

78 The original document, drawn up in Pavia by Battista Codazzi, is no longer to been found among the papers of this notary, at the Archivio di Stato di Pavia. I found a copy, authenticated by the Senate of Milan in 1542, in AGR, Bxl (OFCB) B.1266.

79 The original document, drawn up in Pavia by Battista Codazzi, is no longer to been found among the papers of this notary, at the Archivio di Stato di Pavia. I found a copy, authenticated by the Senate of Milan in 1542, in AGR, Bxl (OFCB) B.1266. 
altro hebreo di qual grado o natione si sia, possi prestar in alcun modo con interesse in detta cittade durante li tre anni de la condotta senza il consenso et licenza di esso Messer Emanuele, sotto pena di cento scudi d'applicarsi per li tre quarti alla Camera Ducale et per l'altro quarto a detto Messer Emanuele, onde volendo dichiarare sopra ciò detto Messer Emanuele la volontà sua, per questo esso Emanuele spontaneamente dichiara, si contenta, consente e vuole che tutti li infrascritti de la sua Natione che sono convenuti et sono d'accordo con esso e anchora quelli che conveneranno et seran d'accordo per l'avvenire, di poi che seranno d'accordo, possino liberamente prestare con interesse e senza pegni però per il tempo de li tre anni de la sua condutta et durante detto tempo, Dechiarando quelli che sin hora sono accordati esser li infrascritti, videlicet: Messer Joseph Tobi, Messer Samuel Binmaiori, Messer Joseph Cavalieri, Messer Mordechai suo fratello, Messer Ioseph et Messer Esdra Namias fratelli, Messer Moise Avensechem et suo suocero, Messer Salomon Atias, Messer Samuel Rubra, Madama Rachela e figlioli Abiacari, Messer Abram Iglioni, Con tutte loro famiglie.

Et inoltre detto Messer Emanuele si contenta liberamente et vuole che tutti li sopradetti con loro famiglie possinio stare e habitare in Pesaro per il detto tempo con la disdetta contenuta nella sopradetta capitulatione et prestare come di sopra. E così quelli che per l'avvenire fossero d'accordo con esso Messer Emanuele, di poi che saranno d'accordo. Et questo fa el predetto Messer Emanuele perché egli confessa li soprascrittj esser obbligati. Et quelli che si accordassero si obbligaranno pagare al detto Messer Emanuele ciascun anno per li doi anni da venir li doi terzi del pagamento che si ha da fare al S.r Duca Jll.mo contenuto nel jnstrumento de l'obligatione fatta per detto Messer Emanuele.

Acta fuerunt haec in Civitate Pisauri in domo habitationis Ser Angeli quondam Zacharie de Volterra hebrei habitatoris Pisauri et habitationis dicti domini Emanuelis sita in quarto Sancti Terentij juxta bona Sinagoge ...

Et Ego Almericus Emilionibus Civis Pisauri publicus notarius appostolica et imperiali auctoritate rogatus [scripsi] ${ }^{80}$.

Doc. 4 (Dec. 7th 1558): Notary Francesco Fattori states that all the goods belonging to Emanuel Bichacho and to Samuel Catalano, his son-in-law, have been seized and inventoried. The two Portuguese are declared absent and fugitive. All their debtors are exempted from repaying their debts.

${ }^{80}$ ASPs (ANA), Notary Almerico Emilioni, Reg. 1536-1557, ff. 450r-452r. 
Jn Christi nomine amen, Anno a nativitate eiusdem Domini nostri quingentesimo quinquagesimo octavo ... tempore Pontificis $\mathrm{S}^{\mathrm{mi}}$ in Christo patris et Domini nostri Domini Pauli divina providentia Pape Quarti die vero septima mensis decembris.

Cum sit et fuerit quod ex commissione Jll. ${ }^{\mathrm{mi}}$ et Ex. ${ }^{\mathrm{mi}}$ Domini nostri Ducis fuerint facta nonnulla jnventaria de quibusdam rebus et bonis mobilibus spectantibus et pertinentibus ad Samuellem Cathelanum et Manuellem Bicciaccium hebreos, olim habitatores Pisauris, per Notarium Maleficiorum et Officiales Curiæ Potestatis Pisauris et superinde fuerunt date diverse fideiussiones et depositarij vocantes se habere et habuisse dictas res et bona mobilia in depositum et eas et ea consignare quotiescumque requisiti fuerint et prout et sicut in jnstrumentis et scripturis huiusmodi superinde factis et celebratis ad quæ et quas maxime brevitatis causa habeatur relatio, unde constitutus Magnificus Dominus Comstantinus Thimotellus civis Pisaurensis et majordomus in presentiarum predicti Jll. ${ }^{m i}$ Domini nostri, expressa comissione predicti Jll. ${ }^{\mathrm{mi}}$ Domini Ducis Urbini, prout ipse dixit et affirmavit habuisse et habere huiusmodi commissionem, cassat, irritat et annullat omnes et quascunque fideiussiones ut supra prestitas dictis de causis et occasionibus ac penitus liberat et absolvit omnes depositarios predictos qui vocaverunt se habuisse et habere dictas res et bona mobilia spectantes et pertinentes et spectantia et pertinentia ad dictos Samuellem et Emanuellem in depositum ut supra et pro cassis, jrritis et annullatis ac dictos depositarios pro absolutis et liberatis a predictis promissionibus per eos factis ex expresso mandato predicti Jll. ${ }^{\mathrm{mi}}$ Domini Ducis prout dixit ut supra habita et haberi voluit et mandavit et jta promisit mihi notario jnfrascripto uti notario et stipulanti et tam pro dictis depositariis et alijs quibuscumque superinde obbligatis quam pro dictis Samuelle et Emanuelle absentibus.

Rogans et promittens et obligans et jurans predicta omnia et singula fuisse et esse vera et observanda et adimplenda ut supra tamquam Majordomus predicti Jll. ${ }^{\mathrm{mi}}$ et quod ut supra prout dixit habuit comissionem et mandatum ita faciendi, absolvendi et liberandi ut supra expressum est. Rogans me notarium ut de predictis omnibus et singuilis pubblicum conficierem jnstrumentum ad cautelam tam sopranominatorum quam aliorum quorumcunque quomodolibet interesse habentium.

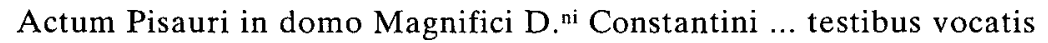
ac rogatis.

Ego Franciscus Factorius civis pisaurensis, publicus apostolica auctoritate notarius his omnibus ac singulis suprascriptis interfui eaque rogatus scribere scripsi et publicum signum meum posui ${ }^{81}$.

${ }^{81}$ ASPs (ANA), Notary Francesco Fattori, Reg. 1554-1558, Dec. 12th 1558. 
Doc. 5 (Dec. 7th 1558): Notary Francesco Fattori states that Ora Bichacho, the daughter of Manuel and the wife of Samuel Catalano has been kept in prison in different places for a long time. Duke Guidobaldo has ordered to set her free.

Jn Christi nomine amen, Anno a nativitate eiusdem Domini quingentesimo quinquagesimo octavo ... tempore Pontificatus S. ${ }^{\mathrm{mi}}$ in Christo patris et Domini nostri Domini Pauli divina providentia Papæ quarti die vero septima mensis decembris.

Cum sit et fuerit quod domina Ora filia Emanuelis Bicciacci et uxor Samuelis Cathelani hebrei fuerit pluries et pluries retenta ex commissione et mandato Jll. ${ }^{\mathrm{mi}}$ et Ex. ${ }^{\mathrm{mi}}$ Domini Ducis nostris in diversis locis in Civitate Pisauri unde constitutus Jllustris Dominus Raynerius ex Marchionibus de Monte et Comes Montis Birotij fidem fecit et retulit qualiter predictus et Jll. ${ }^{\text {mus }}$ et Ex. ${ }^{\text {mus }}$ D. Dux noster ab huiusmodi detentione dictam dominam Oram penitus liberavit et pro liberata haberi voluit et mandavit. Rogans me notarium ut de predictis omnibus et singuilis pubblicum conficiere jnstrumentum pro cautela dicte domine Ore absentis et aliorum quorumcunque quomodolibet interesse habentium seu quomodolibet habiturorum, me notario pro ipsis et quolibet eorum uti notario et stipulante et acceptante ${ }^{82}$.

${ }_{82}$ ASPs (ANA), Notary Francesco Fattori, Reg. 1554-1558, Dec. 12th 1558. 


\section{RESUMEN}

Según Samuel Usque en su Consolaçam as Tribulações de Israel, en 1551 Manuel Bichacho, judío de origen portugués que vivía en Pesaro, convenció al duque de Urbino para que aceptara en sus estados a un grupo de sus compatriotas que habían sido expulsados de Ferrara, acusados de propagar la peste. Sin embargo, el destierro de Ferrara tuvo lugar en el otoño de 1549 y no en 1551. Las investigaciones llevadas a cabo en archivos italianos y belgas nos han permitido identificar al judío portugués Manuel Bichacho, banquero de Pesaro, con Emanuel Lopes, rico mercader marrano de Amberes, que jugó un importante papel como uno de los líderes de la «nación portuguesa» en dicha ciudad y miembro del comité de rescate que organizó y financió la huida de marranos de Portugal a Flandes y desde allí hacia Ferrara y Levante.

\section{SUMMARY}

According to Samuel Usque's Consolaçam as Tribulações de Israel, in 1551, Manuel Bichacho, a Portuguese Jew living in Pesaro, entreated the Duke of Urbino to accept in his States a group of his countrymen who had been expelled from Ferrara, where they had been accused of having brought the plague. However, the desterro from Ferrara took place in the autumn of 1549 and not in 1551. Research carried out in Italian and Belgian Archives allowed us to identify Manuel Bichacho, the Jewish Portuguese banker in Pesaro, with the former Emanuel Lopez, a rich Marrano merchant of Antwerp who played an important role as one of the leaders of the Portuguese Nation in that city, and a member of the Rescue Committee which organised and financed the escape of Marranos from Portugal to Flanders and thence towards Ferrara and the Levant. 